\title{
Effect of Increase of Reinforcement Near Beam - Column Joints in Performance Based Design of Low-RiseBuildings
}

\author{
PoleswaraRaoKovela ${ }^{1}$, Balaji K.V.G.D ${ }^{2}$, GopalRaju S.S.S.V ${ }^{3}$ and SrinivasaRao S $^{4}$ \\ ${ }^{1}$ Research Scholar, GITAM University, Visakhapatnam, Andhra Pradesh, India. \\ E-mail:pr.kovela@gmail.com \\ ${ }^{2}$ Professor of Civil Engineering, GITAM University, Visakhapatnam, Andhra Pradesh India. \\ E-mail:balajigitam@gmail.com \\ ${ }^{3}$ Associate Professor, Dept., of Civil Engineering, IIIT, Nuzividu, Andhra Pradesh India. \\ E-mail: sssvgopalaraju@gmail.com \\ ${ }^{4}$ Head of the Department of Civil Engineering, \\ Government Women Polytechnic, Kakinada, Andhra Pradesh India. \\ E-mail:srsingudasu@gmail.com
}

\begin{abstract}
Due to its simplicity and capability in providing characteristic information that cannot be extracted via elastic static or dynamic analysis,the structural engineering professionhas been using the non linear static procedure (NSP) or pushover analysis. Pushover analysis is carried out for either user defined nonlinear hinge properties or default - hinge properties, available in some programs basedon the FEMA-356 and ATC-40 guidelines. The hinge properties depend upon the sectional properties of the columns / beam members. This paper studies the effect of increase of reinforcement of columns and beams near joints. Due to increase of reinforcement, the moment capacity of the non linear hinge will be increased which results in increase of the base shear capacity of the RCC building. Typical framed structure of 4 story, 5 story and 6 story are analyzed with increased joint reinforcement. Strong column and weak beam Principle is adopted while assuming sectional properties of the frame. The base shearversus displacements curves are compared. Considerable increase of base shear is observed when reinforcement in beams are increased. Very negligible increase of base shear is observed when reinforcement in column are increased.
\end{abstract}

Key words: Nonlinear Hinge,Pushover analysis, Base Shear Capacity.

\section{INTRODUCTION}

Since non linear behavior is intended in most structures subjected to earth quake loading, the use of non linear analysis is essential to capture the behavior of structures under seismic effects. The structural engineering profession has been using the non linear static procedure pushover analysis described in FEMA - 356 and ATC 40. It is widely accepted that, carefully used pushover analysis provides useful information that cannot be obtained by linear static or dynamic analysis procedures.

Modeling is one of the important steps in performing pushover analysis. The model has to consider the nonlinear behavior of the structure. The nonlinear properties of each component in the structure will contribute to the nonlinear behavior of the total structure. The nonlinear properties of the each component depends upon the plastic hinge properties / sectional properties of the members. In RCC framed structures ,the hinge properties of the member depends up on the sectional properties and area of the reinforcement in concrete columns and beams. Based on the sectional properties of the member at theassumed location of hinge formation, the hinge properties will be generated in the well known nonlinear analysis software such as E-TABS and SAP etc.,

If the same members have different sectional properties at different location, the hinge properties also will be changed along the length of the member. The deformation capacity of reinforced concrete structure depends upon the modeling assumptions.

This paper aims at study the effect of the increase of the reinforcement near beam and column joints on the base shear capacities of the total structure in performance based design. Three dimensionalmodeling is employed and E-TABS software programme is used for pushover analysis. 


\section{DESCRIPTION OF THE STRUCTURE:}

Three structures i.e., four, five and six storied are considered to represent low-rise reinforced concrete building for study.

Properties of the Building:-

Type of structure

: Multi-storied moment resistance frame

Size of the Building

: $\quad 24 \mathrm{mx} 18 \mathrm{~m}$

Number of stories

: $\quad$ Three models consisting of

Height of Storey

$$
\text { 4, } 5 \text { and } 6 \text { storey }
$$

Materials

: 3 meters

: Concrete M 25

Wall thickness considered for load

Reinforcement Fe 415

Size of column

: $\quad$ External wall $230 \mathrm{~mm}$ Internal wall $115 \mathrm{~mm}$

Size of the beam

: $\quad 250 \mathrm{~mm} \times 500 \mathrm{~mm}$

Depth of slab

: $\quad 250 \mathrm{~mm} \times 400 \mathrm{~mm}$

Specific weight of the RCC

: $\quad 150 \mathrm{~mm}$

Specific weight of the Wall

: $\quad 25 \mathrm{KN} / \mathrm{m}^{3}$

Live Load

: $20 \mathrm{KN} / \mathrm{m}^{3}$

Floor finish

: $\quad 3 \mathrm{KN} / \mathrm{m}^{2}$

: $\quad 1 \mathrm{KN} / \mathrm{m}^{2}$

The Plan and Elevation are shown in the Fig.1 and Fig.2 Column reinforcement and Beam reinforcement are obtained as per elastic analysis without considering the seismic / wind forces and shown in Fig.3.

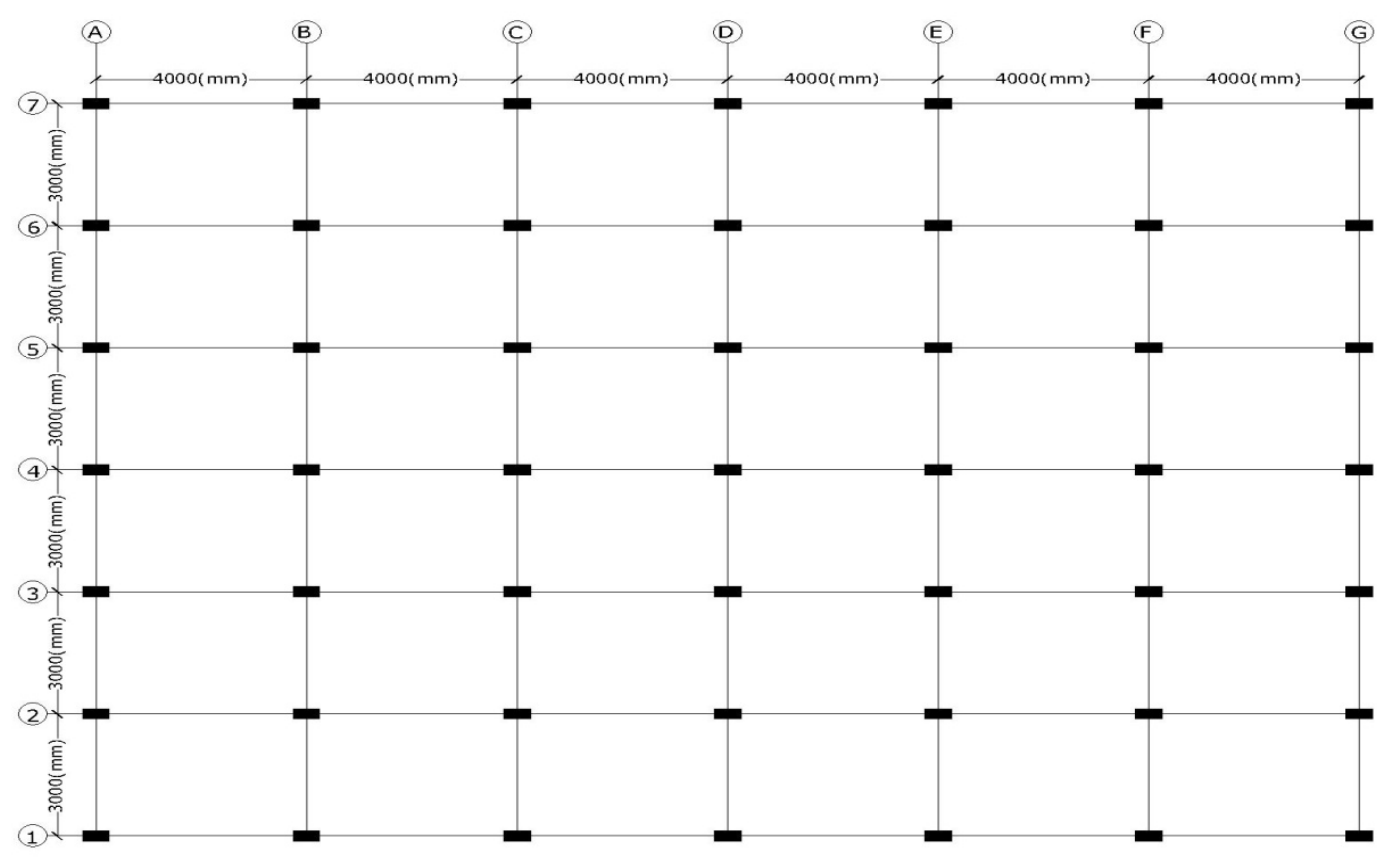

Fig.1 -Typical Plan of RCC Frame 


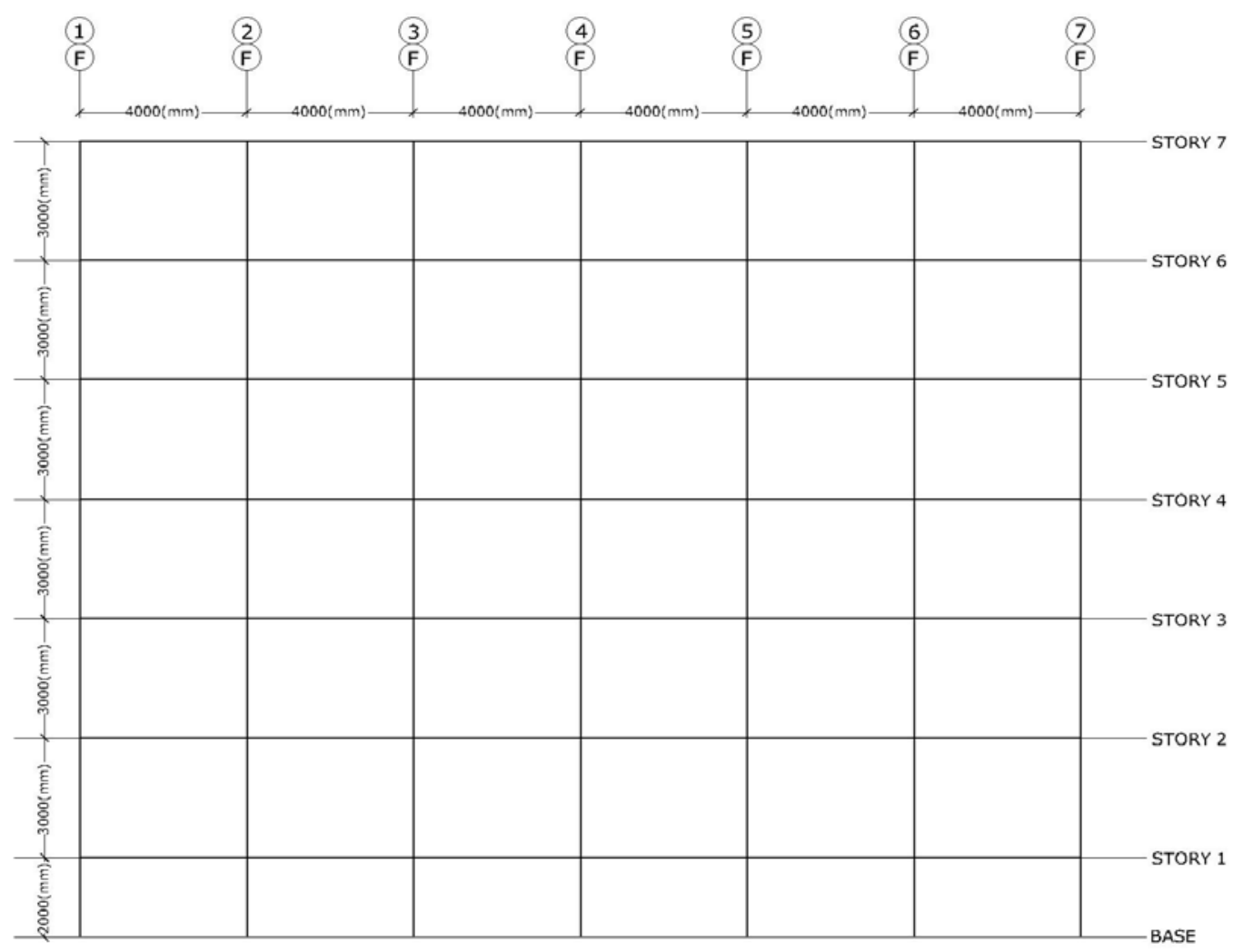

Fig.2 -Elevation 6 Storey Frame

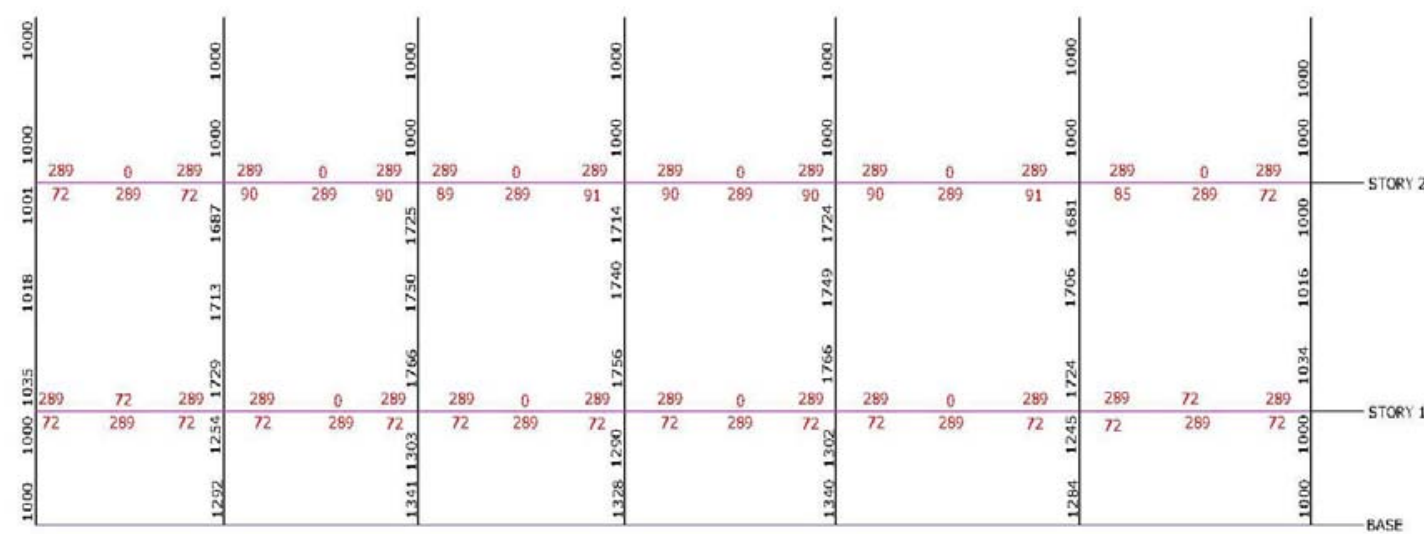

Fig.3 -Required Longitudinal Reinforcement for 6 Storey

\section{Modeling approach:}

Analysis have been performed using ETABS, which is a widely used structural designprogramme for static and dynamic analysis of the structures. A three dimensional model of each structure is created to carryout nonlinear statistic analysis. Beams and columns elements are modeled as nonlinear frame elements with plasticity by defining plastic hinges at both ends of column / beam members. The beam and column are divided into three parts i.e., central half part and quarter part on either side. The $1 / 4$ of the span of the beam and $1 / 4^{\text {th }}$ height of the column on either side of the beam \&column joint are considered for strengthening by increase of reinforcement. The reinforcement in beams and column near joints for a length of $0.25 \mathrm{~L}$ is increased by $25 \%$, $50 \%$ and $75 \%$ for each model for this study. The initial reinforcement in columns and beams is arrived based on the elastic analysis considering only gravity loads. The equivalent reinforcement is provided duly adopting selective combination of different dia of reinforcement barsThe \% of increase is with reference to the initial reinforcement provided based on elastic analysis. The reinforcement provided in beams and columns is shown in Table Iand II. 
The nonlinear hinges are provided on either side of the quarter part and either side of the central half part of beams and columns to allow the failure mechanism in hinges in the central beam and column also, when reinforcement in members near joints is increased. Six Nos. of non linear hinges are provided for each column and beam as shown in figure4.

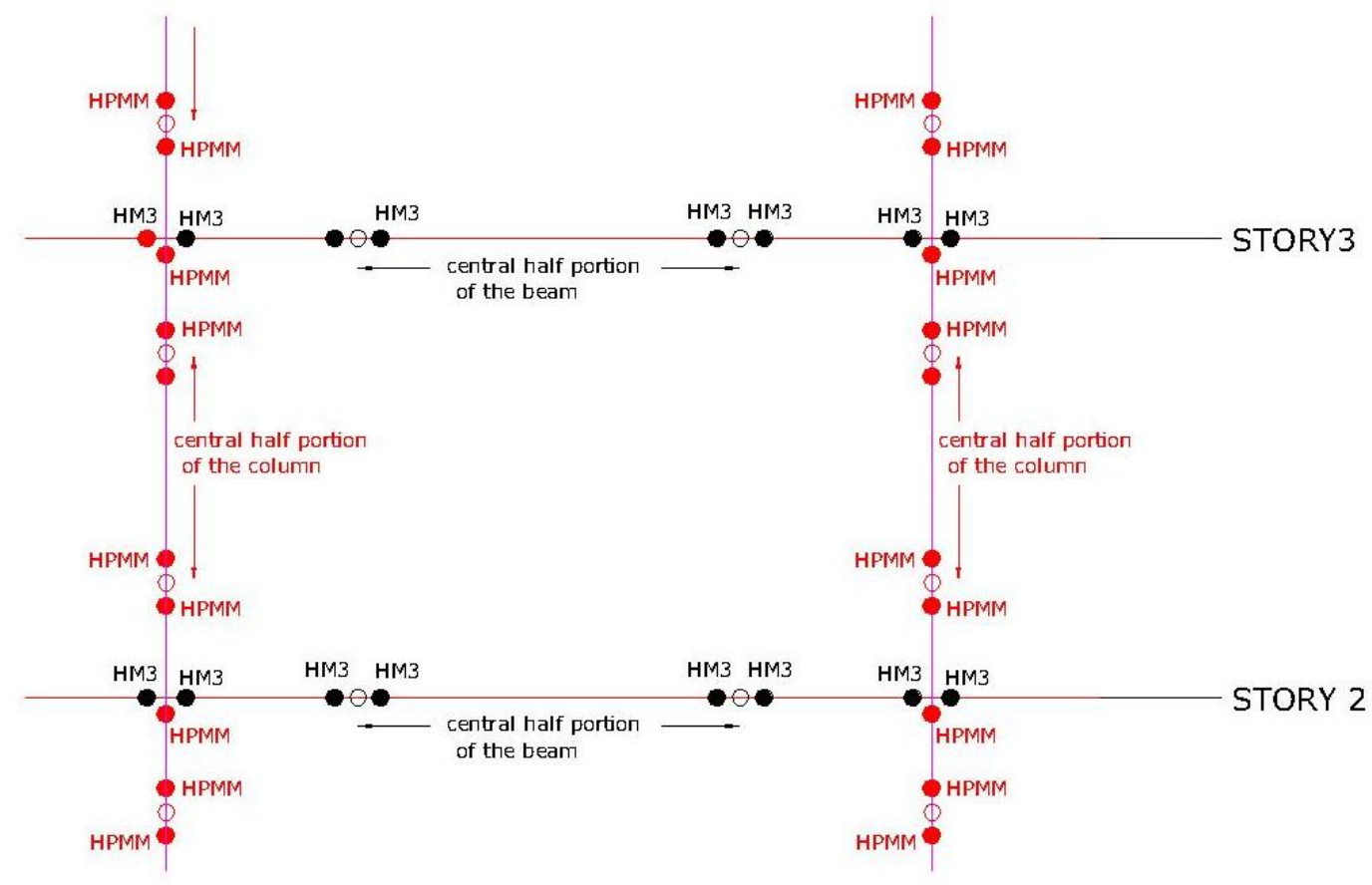

Fig.4 -Hinge Location near Beam Column Joint

ETABS implements the plastic hinge properties described in FEMA 356 (or ATC 40). The curve shown in figure 5labeled A, B, C, D and E define the force-deformation behavior of plastic hinge. Where IO denotes Immediate Occupancy Level, LS denotes Limited Safety Level and CP denote Collapse Prevention level. The values assigned to each of these points vary depending up on the type of element, material properties, longitudinal and transverse steel content and the axial load Level on the element.

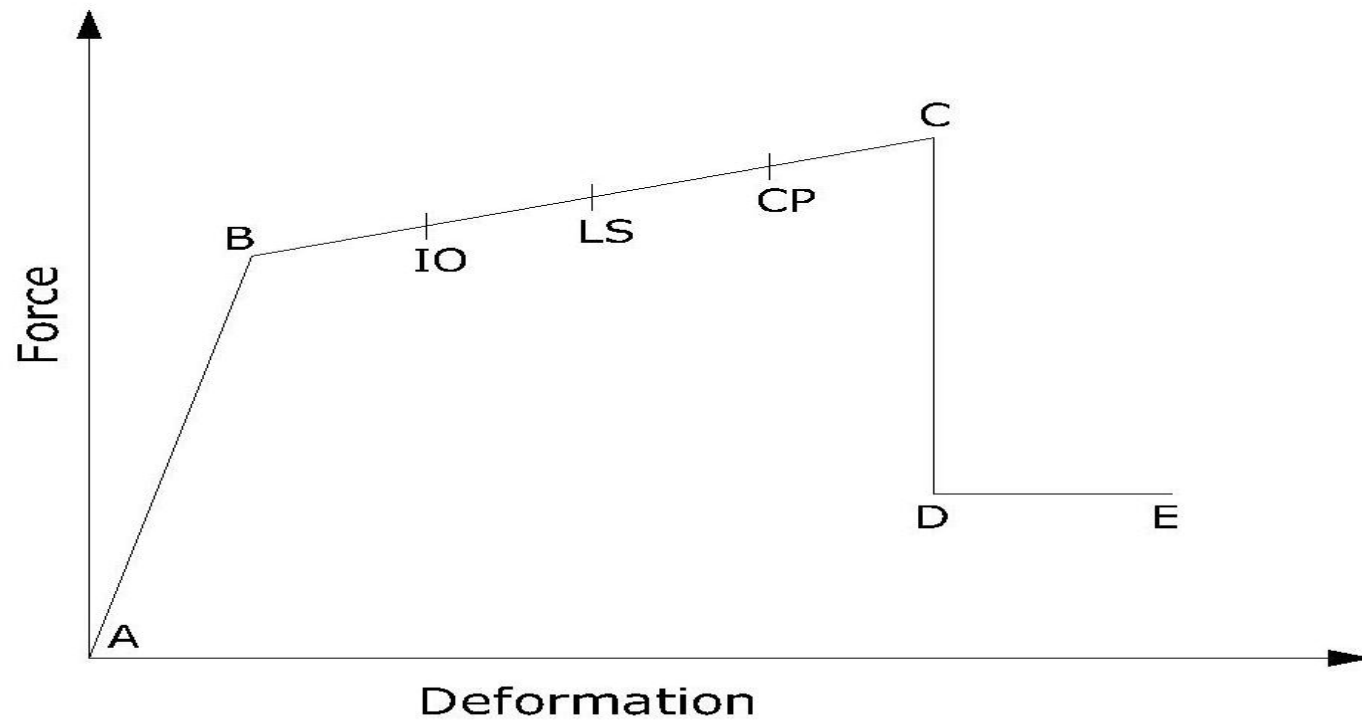

Fig5. - Force Deformation of a Typical Hinge 
ETABS provides default hinge properties and considered PMM hinges for column and M3 hinges for beams. Once the structure is modeled with section properties, steel contents and the loads on it, defaults hinges properties (as per table 10.8 [6] ) will be assigned to the members.

The default hinge properties of the beam depends upon the ratio of $\frac{p-p \prime}{p_{\text {bal }}}, \frac{\mathrm{V}}{\mathrm{b}_{\mathrm{w}} \mathrm{d} \sqrt{\mathrm{f}_{\mathrm{c}}^{\prime}}}$ and column depends up on the ratio of $\frac{\mathrm{P}}{\mathrm{A}_{\mathrm{g}} \mathrm{f}_{\mathrm{c}}^{\prime}}, \frac{\mathrm{A}_{\mathrm{v}}}{\mathrm{b}_{\mathrm{w}} \mathrm{s}}$ where as

$\mathrm{p}=$ Ratio of tension reinforcement, $\mathrm{p}_{\mathrm{bal}}=$ Reinforcement ratio producing balanced strain conditions, $\mathrm{p}^{\prime}=$ Ratio of compression reinforcement, $\mathrm{V}=$ Design shear force at section concurrent with moment,bw $=$ Web width, $\mathrm{d}=$ Distance from extreme compression fiber to centroid of tension reinforcement, $\mathrm{f}_{\mathrm{c}}^{\prime}=$ Compression strength of concrete, $\mathrm{P}=$ Axial force in concrete column, Ag = Gross area of the column, $\mathrm{s}=$ Spacing of shear reinforcement.

The non linear hinge properties of the beam depend up on longitudinal and transverse reinforcement and where as the non linear hinge properties of the column depend up the transverse reinforcement only. It is assumed that the shear reinforcement confirms the required spacing provision in modeling the non linear hinge prosperities.

\section{Pushover analysis:}

The push over analysisconsists of the application of gravity loads and representative lateral load pattern. The building is subjected to gravity loading and simultaneous lateral loading.

There are sixteen models generated for each 4 stories, 5 stories and 6 stories buildings.One of it is the basicmodel with required reinforcement for gravity loading and other fifteen models are with combination of changes in the beam and column reinforcement i.e., 25\%, 50\% and 75\% increase. The pushover curve for displacement in ' $x$ ' direction and ' $y$ ' directionverses base shear are obtained.

Table - I. (Longitudinal Reinforcement provided in Beam)

\begin{tabular}{|c|c|c|c|c|c|c|}
\hline \multirow{2}{*}{$\begin{array}{c}\text { Area } \\
\text { increased } \\
\text { by }\end{array}$} & \multicolumn{2}{|c|}{4 storey } & \multicolumn{2}{|c|}{5 storey } & \multicolumn{2}{|c|}{6 storey } \\
\hline & Top & Bottom & Top & Bottom & Top & Bottom \\
\hline $0 \%$ & $\begin{array}{c}2 \text { Nos. } 16 \\
\text { Dia }\end{array}$ & 2 Nos. 16 Dia & $\begin{array}{l}2 \text { Nos. } 16 \\
\text { Dia }\end{array}$ & 2 Nos. 16 Dia & $\begin{array}{l}2 \text { Nos. } 16 \\
\text { Dia }\end{array}$ & 2 Nos. 16 Dia \\
\hline $25 \%$ & $\begin{array}{c}2 \text { Nos. } 16 \\
\text { Dia }+1 \text { No. } \\
12 \text { Dia }\end{array}$ & $\begin{array}{l}2 \text { Nos. } 16 \text { Dia } \\
+1 \text { No. } 12 \\
\text { Dia }\end{array}$ & $\begin{array}{c}2 \text { Nos. } 16 \\
\text { Dia + } 1 \text { No. } \\
12 \text { Dia }\end{array}$ & $\begin{array}{l}2 \text { Nos. } 16 \text { Dia } \\
+1 \text { No. } 12 \\
\text { Dia }\end{array}$ & $\begin{array}{c}2 \text { Nos. } 16 \\
\text { Dia }+1 \text { No. } \\
12 \text { Dia }\end{array}$ & $\begin{array}{c}2 \text { Nos. } 16 \text { Dia } \\
+1 \text { No. } 12 \\
\text { Dia }\end{array}$ \\
\hline $50 \%$ & $\begin{array}{l}3 \text { Nos. } 16 \\
\text { Dia } \\
\end{array}$ & 3 Nos. 16 Dia & $\begin{array}{c}3 \text { Nos. } 16 \\
\text { Dia }\end{array}$ & 3 Nos. 16 Dia & $\begin{array}{l}3 \text { Nos. } 16 \\
\text { Dia } \\
\end{array}$ & 3 Nos. 16 Dia \\
\hline $75 \%$ & $\begin{array}{c}2 \text { Nos. } 16 \\
\text { Dia + 1No. } \\
20 \text { Dia }\end{array}$ & $\begin{array}{l}2 \text { Nos. } 16 \text { Dia } \\
+1 \text { No. } 20 \\
\text { Dia }\end{array}$ & $\begin{array}{c}2 \text { Nos. } 16 \\
\text { Dia }+1 \text { No. } \\
20 \text { Dia }\end{array}$ & $\begin{array}{l}2 \text { Nos. } 16 \text { Dia } \\
+1 \text { No. } 20 \\
\text { Dia }\end{array}$ & $\begin{array}{c}2 \text { Nos. } 16 \\
\text { Dia + } 1 \text { No. } \\
20 \text { Dia }\end{array}$ & $\begin{array}{c}2 \text { Nos. } 16 \text { Dia } \\
+1 \text { No. } 20 \\
\text { Dia }\end{array}$ \\
\hline
\end{tabular}

Table -II. (Longitudinal Reinforcement provided in Columns )

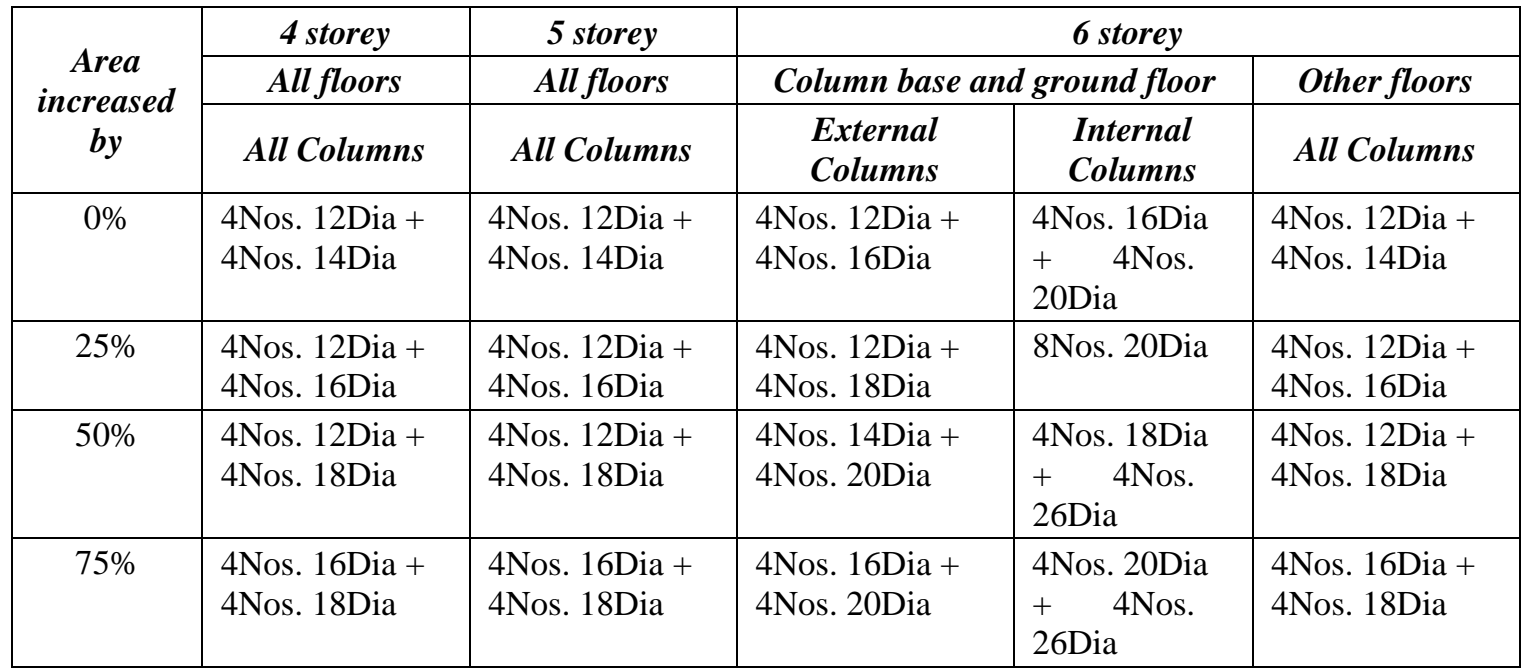




\section{RESULTS AND DISCUSSIONS}

The three Models 4, 5 and 6 storey are analyzed by using "ETABS"software and the results i.e., the maximum displacement versus base shear values are tabulated as below.(Table III to Table VIII)

Table - III. (4 storey Building)

\begin{tabular}{|c|c|c|c|c|}
\hline $\begin{array}{c}\text { Type of } \\
\text { Reinforcement }\end{array}$ & $\begin{array}{l}\text { Deflection in } \\
\text { " } X " \text { direction } \\
\text { (in } \mathrm{mm} \text { ) }\end{array}$ & $\begin{array}{l}\text { Base Shear in } \\
\text { " } X \text { " direction } \\
\text { (in } K N)\end{array}$ & $\begin{array}{l}\text { Deflection in } \\
\text { "Y" direction } \\
\text { (in } \mathrm{mm} \text { ) }\end{array}$ & $\begin{array}{l}\text { Base Shear in } \\
\text { "Y" direction } \\
\text { (in KN) }\end{array}$ \\
\hline 4SB1.00 C 1.00 & 118.023 & 50813.38 & 32.46 & 43594.75 \\
\hline 4SB1.00 C 1.25 & 132.62 & 51498.75 & 32.46 & 43594.75 \\
\hline 4SB1.00 C 1.50 & 129.10 & 52081.61 & 32.46 & 43594.75 \\
\hline 4SB1.00 C 1.75 & 148.56 & 52605.62 & 44.74 & 44110.97 \\
\hline 4SB1.25C 1.00 & 102.45 & 55620.59 & 41.48 & 52587.67 \\
\hline 4SB1.25 C 1.25 & 116.27 & 56322.11 & 83.63 & 54276.53 \\
\hline 4SB1.25C 1.50 & 138.11 & 57101.32 & 88.77 & 54877.39 \\
\hline 4SB1.25 C 1.75 & 140.42 & 57621.57 & 95.72 & 55303.80 \\
\hline 4SB1.50 C 1.00 & 90.70 & 59353.69 & 64.33 & 57080.79 \\
\hline 4SB1.50C 1.25 & 109.69 & 60025.50 & 64.94 & 57487.37 \\
\hline 4SB1.50C 1.50 & 120.87 & 60697.49 & 77.70 & 58288.97 \\
\hline 4SB1.50C 1.75 & 128.22 & 61293.82 & 81.51 & 58920.08 \\
\hline 4SB1.75C 1.00 & 98.46 & 62892.96 & 54.18 & 60877.53 \\
\hline 4SB1.75C 1.25 & 95.96 & 64356.10 & 58.995 & 61281.61 \\
\hline 4SB1.75C 1.50 & 105.84 & 65255.85 & 60.169 & 61983.98 \\
\hline 4SB1.75C 1.75 & 114.16 & 65798.69 & 73.53 & 62632.60 \\
\hline
\end{tabular}

Table - IV. (5 storey Building)

\begin{tabular}{|c|c|c|c|c|}
\hline $\begin{array}{c}\text { Type of } \\
\text { Reinforcement }\end{array}$ & $\begin{array}{l}\text { Deflection in } \\
\text { " } X " \text { direction } \\
\text { (in } \mathrm{mm})\end{array}$ & $\begin{array}{l}\text { Base Shear in } \\
\text { " } X " \text { direction } \\
\text { (in } K N)\end{array}$ & $\begin{array}{l}\text { Deflection in } \\
\text { "Y" direction } \\
\text { (in } \mathrm{mm})\end{array}$ & $\begin{array}{l}\text { Base Shear in } \\
\text { "Y" direction } \\
\text { (in KN) }\end{array}$ \\
\hline 5SB1.00 C 1.00 & 134.63 & 57316.90 & 54.26 & 53580.46 \\
\hline 5SB1.00C 1.25 & 120.50 & 57180.69 & 43.87 & 53388.01 \\
\hline 5SB1.00C 1.50 & 173.06 & 57849.04 & 42.52 & 51102.52 \\
\hline 5SB1.00 C 1.75 & 174.80 & 58105.19 & 32.06 & 47401.72 \\
\hline 5SB1.25 C 1.00 & 146.13 & 62477.24 & 72.91 & 62396.30 \\
\hline 5SB1.25C 1.25 & 141.31 & 63181.46 & 79.13 & 62910.72 \\
\hline 5SB1.25C 1.50 & 143.11 & 63905.40 & 84.26 & 63447.76 \\
\hline 5SB1.25C 1.75 & 154.52 & 64267.79 & 82.30 & 63924.08 \\
\hline 5SB1.50C 1.00 & 132.01 & 66262.40 & 67.07 & 66606.98 \\
\hline 5SB1.50 C 1.25 & 143.46 & 67281.29 & 72.81 & 66968.83 \\
\hline 5SB1.50 C 1.50 & 152.07 & 68148.33 & 66.40 & 67394.66 \\
\hline 5SB1.50 C 1.75 & 146.41 & 68502.80 & 84.38 & 67908.76 \\
\hline 5SB1.75 C 1.00 & 101.37 & 69988.04 & 55.68 & 71248.80 \\
\hline 5SB1.75C 1.25 & 112.69 & 70713.57 & 62.61 & 71962.60 \\
\hline 5SB1.75 C 1.50 & 156.19 & 72885.58 & 67.70 & 72260.25 \\
\hline 5SB1.75C 1.75 & 159.23 & 73088.15 & 71.61 & 72482.51 \\
\hline
\end{tabular}


Table - V. (6 storey Building)

\begin{tabular}{|c|c|c|c|c|}
\hline $\begin{array}{c}\text { Type of } \\
\text { Reinforcement }\end{array}$ & $\begin{array}{c}\text { Deflection in } \\
\text { “ } X \text { " direction } \\
\text { (in } \mathrm{mm})\end{array}$ & $\begin{array}{c}\text { Base Shear in } \\
\text { "X" direction } \\
\text { (in } K N)\end{array}$ & $\begin{array}{c}\text { Deflection in } \\
\text { "Y" direction } \\
\text { (in } \mathrm{mm})\end{array}$ & $\begin{array}{c}\text { Base Shear in } \\
\text { "Y" direction } \\
(\text { in } K N)\end{array}$ \\
\hline 6SB1.00 C 1.00 & 185.00 & 65061.34 & 64.59 & 63361.22 \\
\hline 6SB1.00C 1.25 & 188.27 & 65672.70 & 41.88 & 58469.58 \\
\hline 6SB1.00C 1.50 & 3.379 & 13696.60* & 4.62 & 18189.62* \\
\hline 6SB1.00C 1.75 & 11.227 & 24984.18* & 12.747 & 22111.94* \\
\hline 6SB1.25C 1.00 & 112.29 & 69372.91 & 62.63 & 72535.61 \\
\hline 6SB1.25 C 1.25 & 187.44 & 71752.76 & 73.53 & 72934.49 \\
\hline 6SB1.25C 1.50 & 9.86 & 21977.59* & 11.24 & 19539.43* \\
\hline 6SB1.25C 1.75 & 11.227 & 24984.18* & 12.747 & 22111.94* \\
\hline 6SB1.50C 1.00 & 173.64 & 75121.23 & 51.24 & 74364.43 \\
\hline 6SB1.50C 1.25 & 185.38 & 76151.11 & 50.53 & 74564.46 \\
\hline 6SB1.50C 1.50 & 9.86 & 21977.59* & 11.24 & 19539.43* \\
\hline 6SB1.50C 1.75 & 11.227 & 24984.18* & 12.75 & 22111.94* \\
\hline 6SB1.75C 1.00 & 137.39 & 80064.25 & 47.13 & 74513.61 \\
\hline 6SB1.75C 1.25 & 168.63 & 80959.02 & 47.72 & 74513.13 \\
\hline 6SB1.75C 1.50 & 9.867 & 21977.59* & 11.24 & 19539.43* \\
\hline 6SB1 .75 C 1.75 & 11.227 & 24984.18* & 12.747 & 22111.94* \\
\hline
\end{tabular}

Note: * Due to non convergence of the iteration process, the required results could not be obtained and these values are not considered in analysis.

Table VI. (Increase of Base Shear for Increase of Reinforcement in Columns)

\begin{tabular}{|c|c|c|c|}
\hline $\begin{array}{c}\text { \% increase in } \\
\text { reinforcement }\end{array}$ & Model No. & $\begin{array}{c}\text { \% increase in base } \\
\text { shear (X-Direction) }\end{array}$ & $\begin{array}{c}\text { \% increase in base } \\
\text { shear (Y-Direction) }\end{array}$ \\
\hline \multirow{3}{*}{25} & 4SB1.00 C 1.25 & 1.35 & 0 \\
\cline { 2 - 4 } & 5SB1.00 C 1.25 & 0 & 0 \\
\cline { 2 - 4 } & 6SB1.00 C 1.25 & 0.94 & 0 \\
\hline \multirow{2}{*}{50} & 4SB1.00 C 1.50 & 2.50 & 0 \\
\cline { 2 - 4 } & 5SB1.00 C 1.50 & 0.93 & 0 \\
\cline { 2 - 4 } & 6SB1.00 C 1.50 & - & - \\
\hline \multirow{2}{*}{75} & 4SB1.00 C 1.75 & 3.53 & 1.18 \\
\cline { 2 - 4 } & 5SB1.00 C 1.75 & 1.38 & 0 \\
\cline { 2 - 4 } & 6SB1.00 C 1.75 & - & - \\
\hline
\end{tabular}

Table - VII. (Increase of Base Shear for Increase of Reinforcement only in Beams)

\begin{tabular}{|l|c|c|c|}
\hline $\begin{array}{c}\text { \% increase in } \\
\text { reinforcement }\end{array}$ & Model No. & $\begin{array}{c}\text { \% increase in base } \\
\text { shear (X-Direction) }\end{array}$ & $\begin{array}{c}\text { \% increase in base } \\
\text { shear (Y-Direction) }\end{array}$ \\
\hline 25 & 4SB1.25 C 1.00 & 9.46 & 20.63 \\
\cline { 2 - 4 } & 5SB1.25 C 1.00 & 9.00 & 16.45 \\
\cline { 2 - 4 } & 6SB1.25 C 1.00 & 6.63 & 14.48 \\
\hline \multirow{3}{*}{50} & 4SB1.50 C 1.00 & 16.81 & 30.94 \\
\cline { 2 - 4 } & 5SB1.50 C 1.00 & 15.61 & 24.31 \\
\cline { 2 - 4 } & 6SB1.50 C 1.00 & 15.46 & 17.37 \\
\hline 75 & 4SB1.75 C 1.00 & 25.74 & 39.64 \\
\cline { 2 - 4 } & 5SB1.75 C 1.00 & 22.00 & 32.98 \\
\cline { 2 - 4 } & 6SB1.75 C 1.00 & 23.06 & 17.67 \\
\hline
\end{tabular}


Table - VIII. (Increase of Base Shear for Increase of Reinforcement in Both Columns and Beams)

\begin{tabular}{|c|c|c|c|}
\hline $\begin{array}{c}\text { \% increase in } \\
\text { reinforcement }\end{array}$ & Model No. & $\begin{array}{c}\text { \% increase in base } \\
\text { shear (X-Direction) }\end{array}$ & $\begin{array}{c}\text { \% increase in base shear } \\
\text { (Y-Direction) }\end{array}$ \\
\hline \multirow{3}{*}{25} & 4SB1.25 C 1.25 & 10.84 & 24.5 \\
\cline { 2 - 4 } & 5SB1.25 C 1.25 & 10.23 & 17.41 \\
\cline { 2 - 4 } & 6SB1.25 C 1.25 & 10.28 & 15.11 \\
\hline \multirow{3}{*}{50} & 4SB1.50 C 1.50 & 19.45 & 33.71 \\
\cline { 2 - 4 } & 5SB1.50 C 1.50 & 18.90 & 25.78 \\
\cline { 2 - 4 } & 6SB1.50 C 1.50 & - & - \\
\hline \multirow{2}{*}{75} & 4SB1.75 C 1.75 & 29.49 & 43.67 \\
\cline { 2 - 4 } & 5SB1.75 C 1.75 & 27.52 & 35.28 \\
\cline { 2 - 4 } & 6SB1.75 C 1.75 & - & - \\
\hline
\end{tabular}
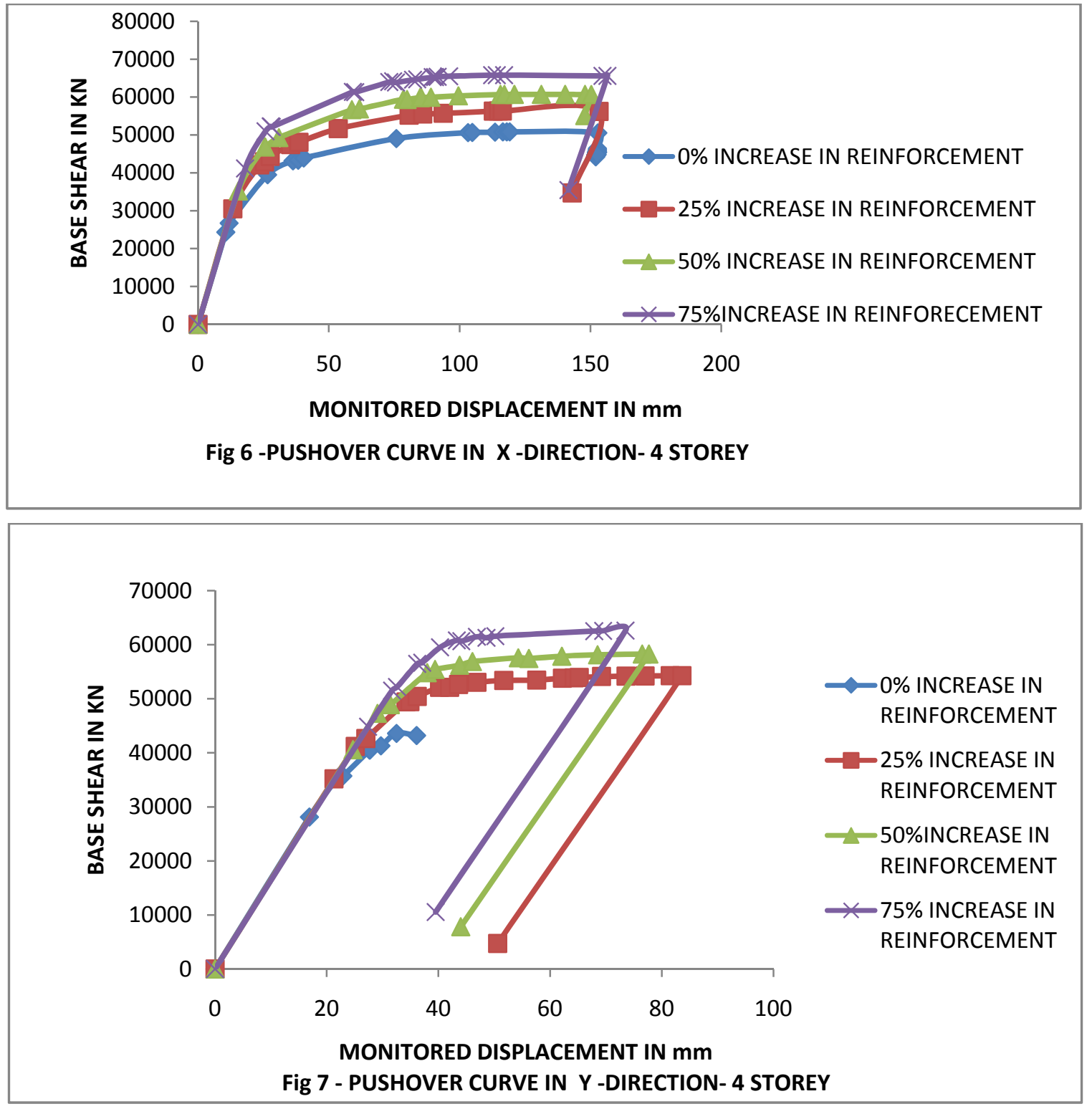

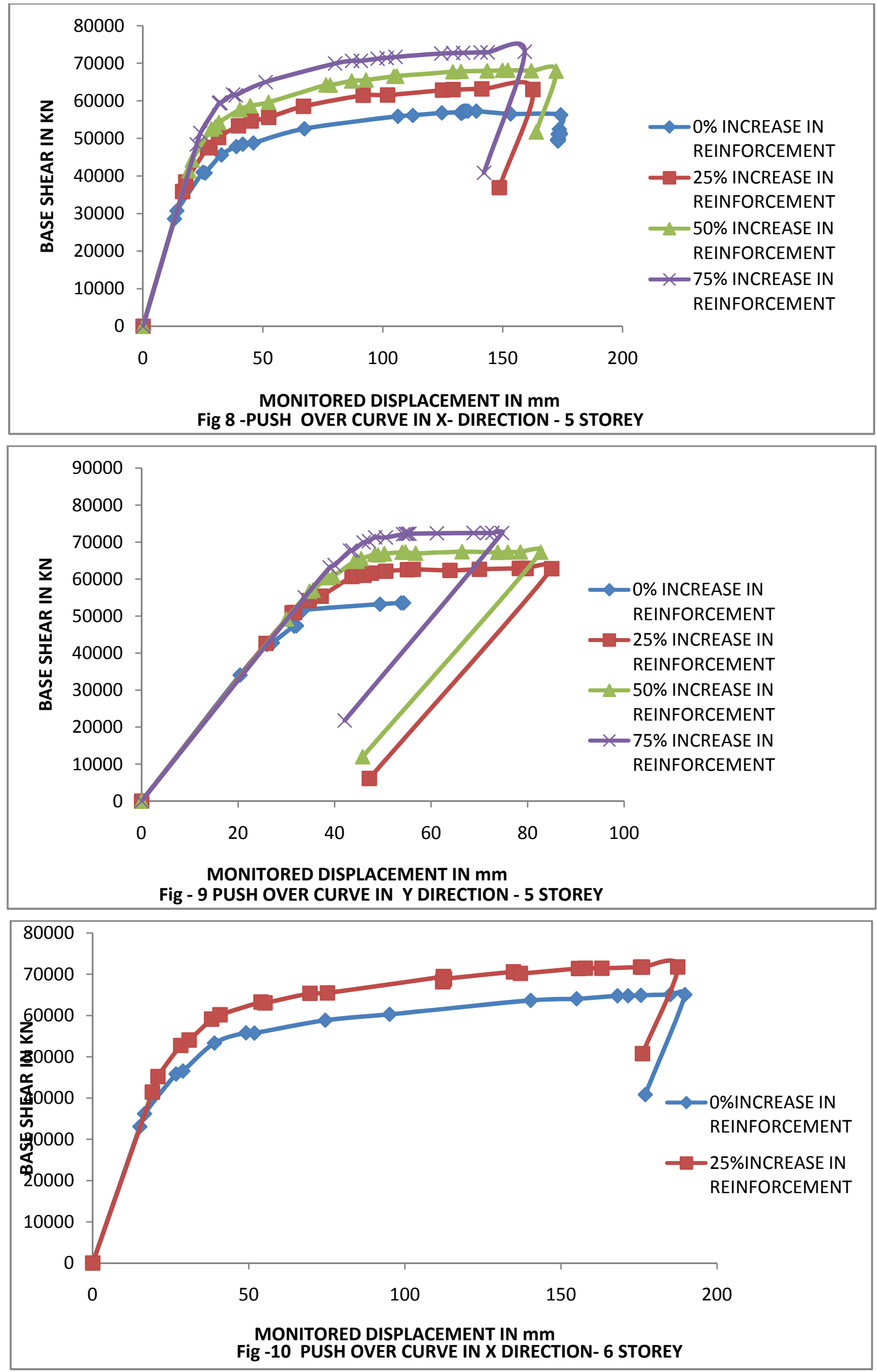

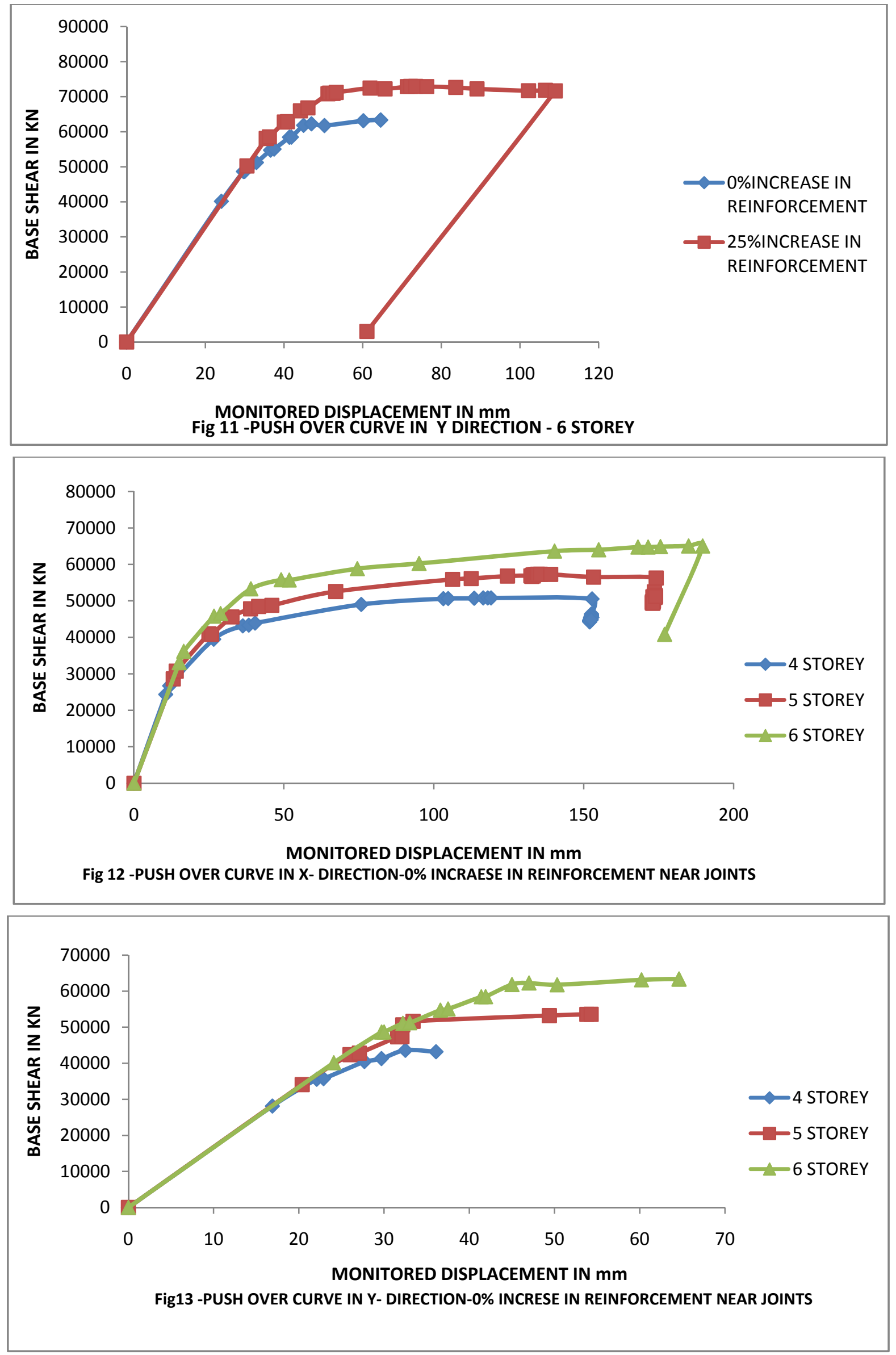

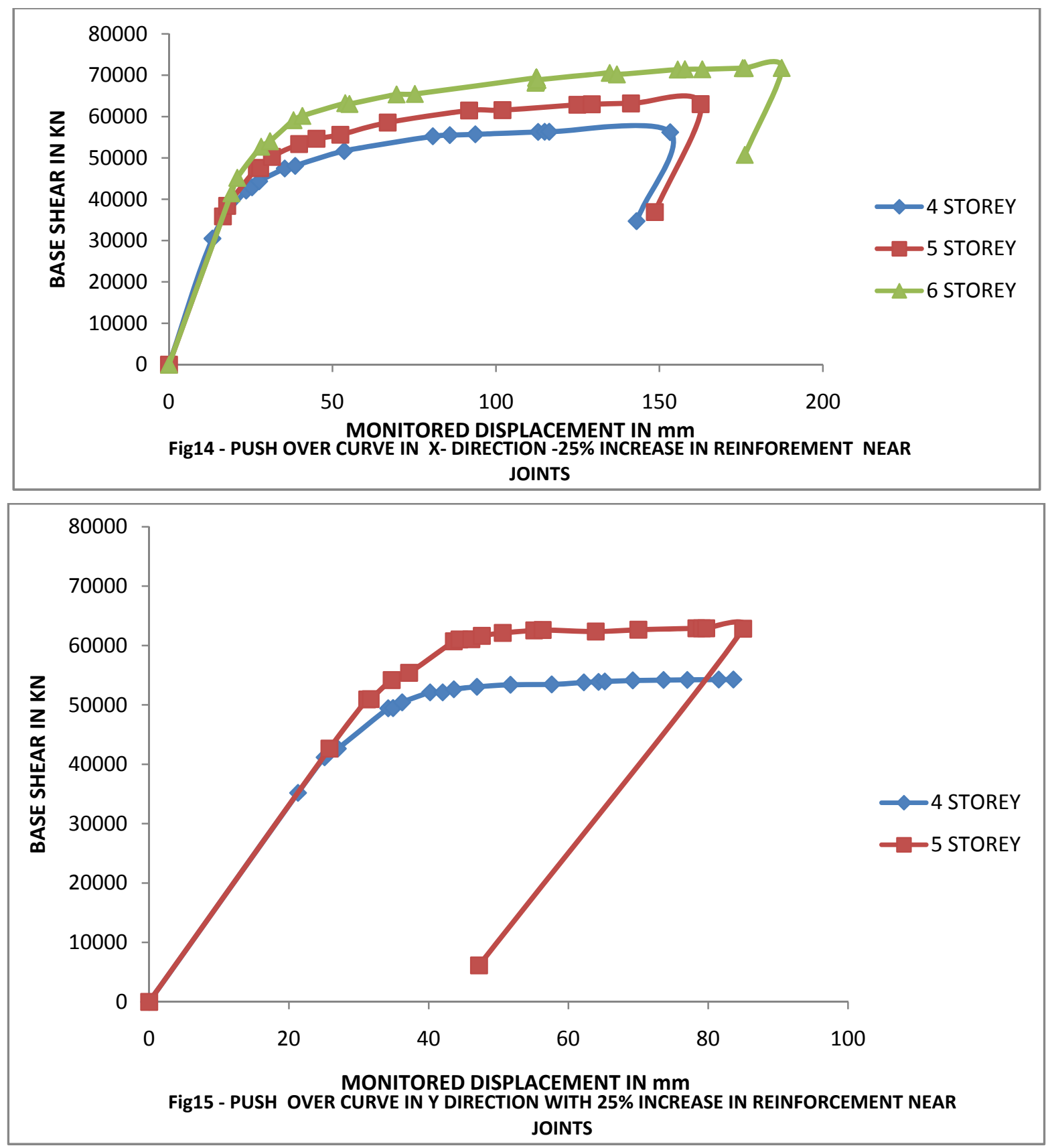

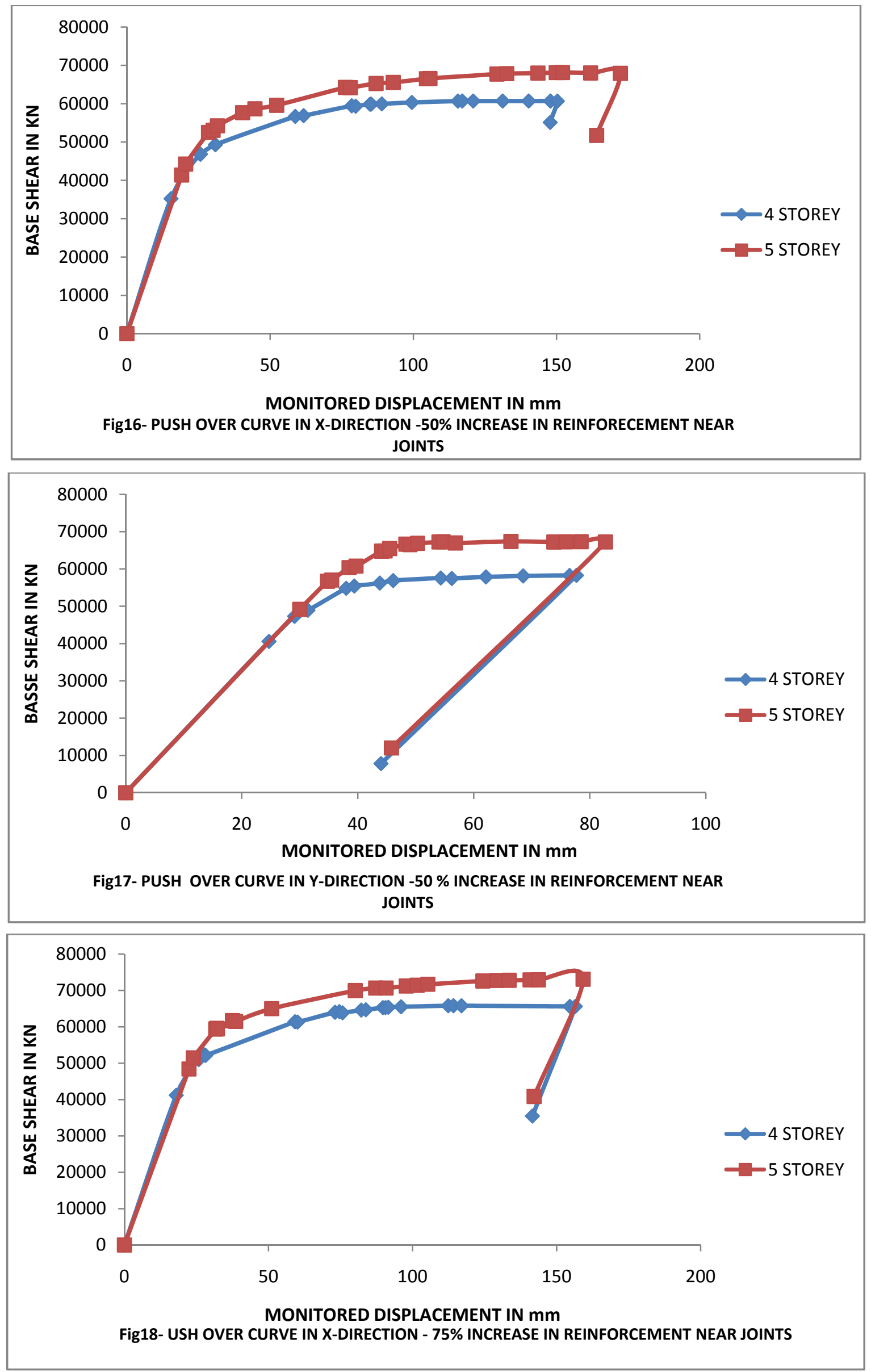


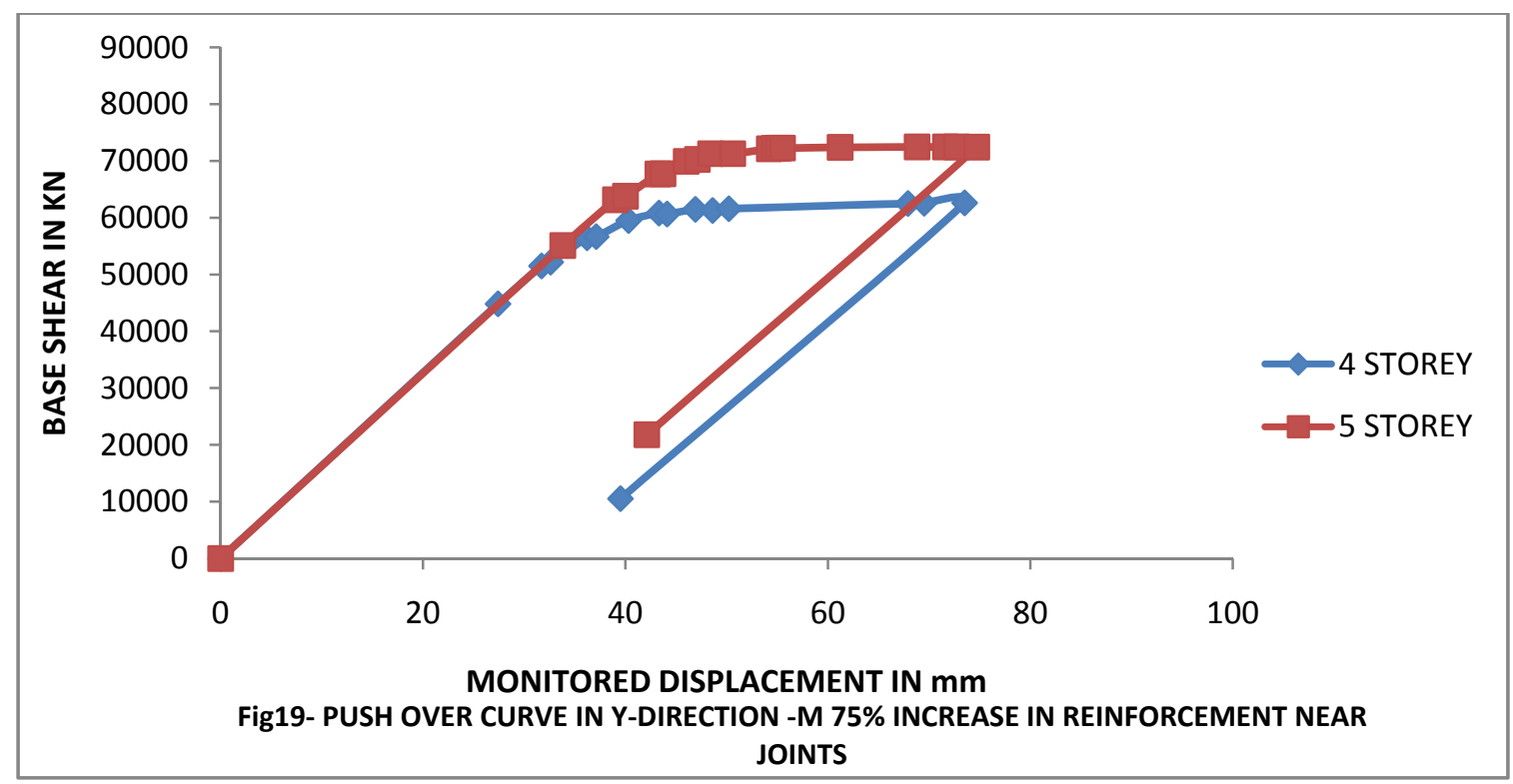

The following observations are made from the results obtained.

1) The base shear capacity of the RCC building is considerably increased by increasing the reinforcement in beams near beam - column joints.

2) (a) The base shear capacity of the building in ' $X$ ' direction is increased upto $30 \%$ by increase of $75 \%$ reinforcement in beams and columns near joints. The increase is reduced gradually from $4^{\text {th }}$ story to 6 story building.

(b) The base shear capacity of the building in ' $\mathrm{Y}$ ' direction is increasedupto $43 \%$. The increase is reduced gradually from 4 story and 6 story.

3) (a)The base shear capacity in ' $x$ ' direction is increased upto $25 \%$ for increase of $75 \%$ of only beam reinforcement.

(b)The base shear capacity in ' $y$ ' direction is increased upto $39 \%$ for increase of $75 \%$ only beam reinforcement near joints.

4) The increase of base shear capacity in both ' $\mathrm{X}$ ' and ' $\mathrm{Y}$ ' direction is very negligible when only column reinforcement is increased.

5) In general the increase in base shear capacity in ' $\mathrm{Y}$ ' direction is more when comparative to the increase in $\mathrm{X}$ directions.

It may be mainly due to the more stiffness of the building in ' $\mathrm{X}$ ' direction when comparative to the ' $\mathrm{Y}$ ' direction.

The reasons for the negligible increase in base shear capacity when only column reinforcement near joints is increased may be due to the fact that

(i) The model is designed such that strong column and weak beam principle is followed.

(ii) The hinge properties of the column do not depend on the longitudinal reinforcement of the column

\section{CONCLUSIONS}

1) The increase in the reinforcement in column joints has negligible impact in base shear capacity of the building

2) The increase in the reinforcement of beam joints has substantial impact on the base shear capacity for the low raise buildings (4 to 6 stories which are commonly adopted).

3) The increase in base shear capacity in Y direction (weaker direction) is more.

4) The increase in base shear capacity due to increase of reinforcement at joints is slightly decreasing with increase of number of floors.

5) The seismic design of low rise buildings for severe earthquake zone also can be more economically designed by this performance based nonlinear static pushover analysis method. 


\section{REFERENCES}

[1] Applied Technology Council (ATC-40), “Seismic evaluation and retrofit of concrete buildings”, Redwood City California Safety Commission, November 1996.

[2] Federal Emergency Management Agency (FEMA 273), "NEHRP guidelines for the seismic rehabilitation of buildings", Washington DC, U.S.A., October 1997.

[3] Federal emergency management agency (FEMA 356), "Prestandard and commentary for the seismic rehabilitation of buildings", Washington, DC, U.S.A., November 2000.

[4] IS 456:2000, "Plain and Reinforced concrete - Code of practice”, Bureau of Indian Standards, New Delhi.

[5] IS 1893-2002 (Part-1), "Criteria for Earthquake resistant design of structures”, General provisions and buildings, Bureau of Indian Standards, New Delhi.

[6] ASCE/SEI 41-13, Seismic Evaluation and Retrofit of Existing Buildings, American Society of Civil Engineers.

[7] Mehmet Inel,HayriBaytanOzmen (2006),Effects of Plastic Hinge properties in Non - Linear analysis of Concrete Buildings, Engineering Structures 28 pp (1494-1502) 